\title{
Celebrating UNAM-Oshakati Campus health day/world health day: a community service: professional and personal life experiences
}

\author{
Lusia N. Pinehas *, NN. Shifiona, KKI. Shikongo \\ Faculty of Health Sciences, School of Nursing and Public Health, University of Namibia: Namibia \\ *Corresponding author E-mail: lpinehas@unam.na
}

\begin{abstract}
Background: The University of Namibia-Oshakati Campus has a tradition to celebrate UNAM Health Day which coincided with the World Health Day annually. The day had always been celebrated within the Oshakati Campus premises. Nurse lecturers from the School of Nursing and Public Health always decide on the activities of the day and they volunteered themselves to take part in the event. The activities conducted were such as blood pressure monitoring, taking of weigh and giving general health education on different topics. In that case activities only catered for the University's staff members, some students and few distance students and individuals who might find them visiting the campus during that day. This year (2013), lecturers celebrated UNAM/World day on the 04th April and they decided to move out of the campus to the nearby "open market" community to sell their service and to raise awareness about the reality of diseases such as hypertension, diabetes mellitus, and obesity under the theme: "High blood pressure" (WHO's theme of the year).

The "open market" is a place in Oshakati (Oshana region) in the northern Namibia where many self-employed local small- and medium business people, males and females gather to sell local food and some "okapana" (takeaways) to passerby.

Aim: The aim is to take the service to the community around Oshakati to sell their service and to raise awareness about the reality of diseases such as hypertension, diabetes mellitus, and obesity under the theme: "High blood pressure".

Method: No actual research was done. The service was carried out in April 2013.

Results: No actual data analysis was done. The analysis of the findings was based on the users of the services. Many people who used the services were found to have high blood pressure up to $229 / 124 \mathrm{mmHg}$, many of the women who sell "okapana" are overweight and seem to have lack the knowledge about balanced diet because they could not understand why they are overweight compared to their Body Mass Index (BMI). They prefer to keep their "fatness" because if they lose weight they will be laughed at and said to have AIDS. Many people were found to have high blood glucose levels $(33.3 \mathrm{mmol} / \mathrm{L})$.

Conclusion: The results indicate the need for health care providers to strengthen the community services and outreach to improve the knowledge and understanding of community members on the need for undergoing regular screening.
\end{abstract}

Keywords: Blood Glucose Level, Health Education, High Blood Pressure, Body Mass Index, Obesity.

\section{Introduction}

Community service is one of the three core functions of lecturers at the University of Namibia. Due to the increase in chronic conditions in Namibia, lecturers at Oshakati campus decided to conduct a community service by conducting screening services for high blood pressure, blood glucose level, and weighing; create awareness about the causes and consequences of high blood pressure; obesity and diabetes mellitus; and to encourage community members to live healthy lifestyles.

According to the WHO reports, one in three adults has high blood pressure world- wide which gives increase to the risk of heart attacks, stroke and kidney failure. Unfounded reports indicate that there is an increase in chronic conditions in the Northern Namibia. These include conditions such as hypertension, diabetes mellitus and high cholesterol among others.

The term hypertension according to Thompson (2002) refers to a blood pressure reading of: $140-159 / 90-99 \mathrm{mmHg}$ (mild) in stage $1 ; 160-179 / 100-109 \mathrm{mmHg}$ (moderate) in stage $2 ; \geq 180 / 110 \mathrm{mmHg}$ (severe) in stage 3 ; and $\geq 210 / \geq 120 \mathrm{mmHg}$ (very severe) in stage 4 in two consecutive measurements. For this exercise all blood pressure readings of $140 / 90 \mathrm{mmHg}$ were regarded high; $130 / 85 \mathrm{mmHg}$ moderate and $130-139 / 85-89 \mathrm{mmHg}$ high normal.

Obesity is described as any weigh greater than the average weight of an individual in relation to his/her height and age using the BMI chart (MoHSS 2010).

Blood glucose levels are the levels of glucose in the blood as determined by the testing device. The individual is said to be diabetic when the blood glucose levels are elevated in cases of absolute or relative lack of insulin (diabetes mellitus), two hours after a meal $(\geq 100 \mathrm{mg} / \mathrm{dL})$ in two consecutive tests, after 8 hours of fasting $(\geq 126 \mathrm{mg} / \mathrm{dL}$ ) or randomly (Sandra 2006).

\section{Methods}

No actual research was done. The activities were carried out in April 2013. The activities were carried out on street vendors at Oshakati open market, members of the media who captured the event as well as the community member surrounding the Oshakati 
open market and community members from rural area who visited the open market on that specific day.

\subsection{Ethical issues}

All participants were informed of the purpose of the activities, the voluntary nature of the screening, their autonomy, confidentiality as well as anonymity during the time of the screening period.

\section{Results}

\subsection{Blood pressure monitoring}

Table 1: The table below shows the number of adult clients (males and females) for blood pressure (18-78 years)

\begin{tabular}{llllllll}
$\begin{array}{l}\text { To- } \\
\text { tal }\end{array}$ & $\begin{array}{l}\text { Mal } \\
\text { es }\end{array}$ & $\begin{array}{l}\text { Fe- } \\
\text { males }\end{array}$ & $\begin{array}{l}\text { Nor- } \\
\text { mal }\end{array}$ & $\begin{array}{l}\text { High } \\
\text { nor- } \\
\text { mal }\end{array}$ & $\begin{array}{l}\text { High; } \\
\text { not on } \\
\text { treat- } \\
\text { ment }\end{array}$ & $\begin{array}{l}\text { High; } \\
\text { on } \\
\text { treat- } \\
\text { ment }\end{array}$ & $\begin{array}{l}\text { Low } \\
\text { blood } \\
\text { pres- } \\
\text { sure }\end{array}$ \\
\hline 373 & 79 & 294 & 214 & 58 & 79 & 19 & 3 \\
\hline
\end{tabular}

\subsection{Body mass index}

Table 2: The table below shows the number of clients (adults and children) whose weight was measured; and the calculation of the BMI

\begin{tabular}{lllllllll}
\hline $\begin{array}{l}\text { To } \\
\text { tal }\end{array}$ & $\begin{array}{l}\text { Ma } \\
\text { les }\end{array}$ & $\begin{array}{l}\text { Fe- } \\
\text { male } \\
\text { s }\end{array}$ & $\begin{array}{l}\text { Chil } \\
\text { dren }\end{array}$ & $\begin{array}{l}\text { Nor } \\
\text { mal }\end{array}$ & $\begin{array}{l}\text { Under- } \\
\text { weight }\end{array}$ & $\begin{array}{l}\text { Mod- } \\
\text { erate }\end{array}$ & $\begin{array}{l}\text { Over- } \\
\text { weight }\end{array}$ & $\begin{array}{l}\text { Ob } \\
\text { ese }\end{array}$ \\
\hline $\begin{array}{l}20 \\
8\end{array}$ & 48 & 160 & 8 & 79 & none & 4 & 61 & 64 \\
\hline
\end{tabular}

\subsection{Blood glucose monitoring}

Table 3: The table below shows the blood glucose level

\begin{tabular}{llllll}
\hline Total & Males & Females & $\begin{array}{l}\text { Low } \\
\text { blood } \\
\text { glucose } \\
\text { level }\end{array}$ & $\begin{array}{l}\text { Diabetes } \\
\text { mellitus on } \\
\text { treatment }\end{array}$ & $\begin{array}{l}\text { High blood } \\
\text { glucose level } \\
\text { detected } \\
\text { and referred } \\
\text { to the clin- } \\
\text { ic/Dr. }\end{array}$ \\
\hline 246 & 49 & 197 & 1 & 3 & 10 \\
\hline
\end{tabular}

\section{Discussions}

Community members were also excited to have their parameters checked.

\subsection{Blood pressure monitoring}

The total number of the clients whose blood pressure was measured was three hundred and seventy three (373). Their ages varied between 18 and 78 years. Among them seventy nine (79) client's blood pressure was found high. They indicated that their blood pressure was high on one or two occasions but no medications were prescribed. Among this group are those that they do not feel sick and therefore not worry about getting treated. While the rest of the group did not know that their blood pressure is high. About nineteen clients whose blood pressure was found high were on anti-hypertensive treatment. Among this group there are those who indicated having started the anti-hypertensive medications but stopped on their own because they feel "fine" and are not "sick" anymore. This is an indication of lack of knowledge. Some clients indicated that they have their medications but only drinking them when they feel sick that day. This indicates non-adherence and non-compliance. Some said when they are busy or in a hurry they tend to forget to take their medications. One client was made to take her medication on spot because her blood pressure was $229 / 124 \mathrm{mmHg}$, because she was in a hurry that day, she had no time to drink her Moduretic tablet which is taken once per day which she had in her bag. She was made to sit and rest for an hour (but disappeared to do her duties), when she came back the blood pressure was still very high. She was again instructed to sit and rest under close observation; blood pressure tested and then made to take her tablet under supervision. Health education was given to her regarding adherence and compliance to medications as well as complications of hypertension.

Every client whose blood pressure was found elevated for the first time was instructed to rest for 30 minutes to one hour, blood pressure was re-checked if still high health education was given on diet, regular check-ups, and referred to the doctor. Many clients whose blood pressure was found high indicated that one or two family members also have a high blood pressure. Some of the clients indicated having stressful living conditions that might have contributed to their high blood pressure.

Every client was given individual health education on diet, changing of lifestyle (avoidance of stress, anger, frustration, alcohol and cessation of smoking), and going for regular medical check-ups, rest and exercise as well as adherence to treatment.

\subsection{Measurement of the weight and the calculation of the Body Mass Index (BMI)}

The Body Mass Index of the clients was calculated in relation to their weight. The responsible staff used the Body Mass Index chart designed by the Ministry of Health and Social Services [MoHSS] (Namibia) in partnership with the USAID, AED, FANTA and UNICEF.

Most of the clients who were overweight and obese are the selfemployed women who sell "okapana" (well fried food and braai). They could not understand how or what makes them "fat" because they eat less food. They seem to have lack of knowledge about balanced diet and exercise and have no time to go for medical check-ups as they lose their customers. When given health education on weight reduction many are afraid to reduce their weight because there is a myth going around in the community that people that look thin or slender have AIDS. They prefer to keep "fatness".

Individual health education was given to every client on diet, exercise, regular weight and blood pressure monitoring. Children who came for weight monitoring their weight were found normal for their age. Their mothers were encouraged to keep their children's weight within the normal ranges and to take them for growth monitoring at the nearest clinic every month.

\subsection{Blood glucose level (hemogluco test)}

According to Thompson et al. (2002), Mogotlane et al. (2013), Nettina (2006), Smeltzer et al. (2010) and Sandra (2006) the normal blood glucose level is between $4.4-6.1 \mathrm{mmol} / \mathrm{L}$ (79.2$110 \mathrm{mg} / \mathrm{dL}$ ). Blood glucose level is expected to rise after a meal but not high than $10 \mathrm{mmol} / \mathrm{L}(180 \mathrm{mg} / \mathrm{dL})$. If the blood glucose is high 2 hours after a meal at two occasions the person is regarded to be diabetic. A fasting blood glucose of 5-7.2 $\mathrm{mmol} / \mathrm{l}$ (90$130 \mathrm{mg} / \mathrm{dL}$ ) in a person who did not eat 8 hours before the test on two occasions is high.

A case was detected whereby the client had a blood glucose level of $33.3 \mathrm{mmol} / \mathrm{L}$ and was sent to the clinic urgently for further management. All clients were given relevant health education whether on treatment or not.

\section{Challenges}

- Shortage of equipments especially the hemogluco test stripsand cholesterol machine was a major challenge

- The time lecturers spent in the field was short

- Community members were disappointed when they learnt that the time is short and that some activities cannot continue due to lack of equipments 
- Community members wanted many services such as voluntary counselling and testing which was not part of the day's activities

\section{Limitations}

The results were an eye opener to the academic staff who were involved in the activity as they provide a rich description of how some of the community members live with health problems without knowing it but the generalization of the findings to the larger community is limited.

\section{Conclusions and recommendations}

The results identified the need of the Ministry of Health and Social Services (Namibia) to establish a mobile clinic at Oshakati "open market" ("omatala") to cater for community members who cannot go for medical check-up to the hospital or health centre. The results indicates the need for the dissemination of health information to the community hence, the need for the exercise to be repeated more often in a year even when it is not a celebration of the health day (during recesses) and that more activities be planned and organised than the first one. Proper planning/budgeting for equipments should be done. Routine screening should be conducted in the community, especially where many people gather such as at shopping complexes, open markets etc. There is a need to bridge the gap between the University of Namibia and the Ministry of Health and Social Services for quality services and improved inter-sectoral collaboration. There should be a strong reporting system to be created between the University of Namibia and the Ministry of Health and Social Services. A report to be written to the regional health office to explain that the community service rendered by the University of Namibia to the local community is not a "private service". All nursing lecturers need to be involved. The interaction with community members was both a professional and learning life experience. Community members showed eagerness to know much about nursing and medical related issues. Planning the health care services should be done in collaboration with community members.

\section{Acknowledgements}

The authors acknowledge the work done by team members and would like to express her profound appreciation to the individuals and the community members who avail themselves for screening for making the event successful.

\section{References}

[1] Ministry of Health and Social Services, (2010), Nutrition assessment, counseling and support for PLHIV: Operational Guidelines, Namibia.

[2] Miller BF, Kreane CB, (1987), Encyclopedia and Dictionary of Medicine, Nursing, and Allied Health. $4^{\text {th }}$ edition. Saunders: Philadelphia.

[3] Mogotlane S, Chauke M, Matlakala M, Mokoena J, Young A (2013), Juta's Complete Textbook of Medical Surgical Nursing. Juta \& Company LTD, Cape Town.

[4] Mosby, (2009) Mosby's Medical Dictionary. $8^{\text {th }}$ edition. Mosby Elsevier, USA.

[5] Nettina SM., (2006), Lippincott Manual of Nursing Practice. $8^{\text {th }}$ edition. Lippincott Williams \& Wilkins: Philadelphia.

[6] Smeltzer SC, Bare BG, Hinkle JL, Cheever KH, (2010), Brunner \& Suddarth's Textbook of Medical- Surgical Nursing. $12^{\text {th }}$ edition. Wolters Kluwer| Lippincott Williams \& Wilkins, Printed in China.

[7] Thompson, JM., McFarland GK., Hirsch JE, \& Tucker SM (2002), Mosby's Clinical Nursing. $5^{\text {th }}$ edition. Mosby, California. 